\title{
The Impact of Foreign Direct Investment on Economic Growth: A Case Study of Turkey 1980-2012
}

\author{
Ahmed Abdulrahman Khder Aga ${ }^{1}$ \\ ${ }^{1}$ Directorate of Economic Planning, Ministry of Planning, Kurdistan Region of Iraq \\ Correspondence: Ahmed Abdulrahman Khder Aga, Directorate of Economic Planning, Ministry of Planning, \\ Erbil, Kurdistan Region of Iraq. E-mail: nweger2005@yahoo.com
}

Received: March 17, 2014

Accepted: April 28, 2014

Online Published: June 25, 2014

doi:10.5539/ijef.v6n7p71

URL: http://dx.doi.org/10.5539/ijef.v6n7p71

\begin{abstract}
This paper employs time series techniques to analyse the effect of foreign direct investment on economic growth in Turkey. The study uses annual data over the period 1980-2012. The gross domestic product (GDP) is the dependent variable and foreign direct investment (FDI), domestic investment (DIN) and trade liberalization (TL) are the explanatory variables. The empirical analysis starts with run ordinary least square (OLS). The result of Augmented Dickey Fuller (ADF) test hence shows that the series are non-stationary in the level form and stationary in the first difference. The paper further utilises the Johansen cointegration test whereby it finds no cointegration and long run relationship between variables. This study uses Vector Autoregression (VAR) model in order to find the causality. The result demonstrates that there is no causality linkage between GDP with both FDI and DIN. At the same time, there is one-way causality between GDP and trade liberalisation (TL) in the context of Turkey. On the other hand, it is found that there is statistically insignificant yet positive short run impact of foreign direct investment on gross domestic product (GDP) while OLS is used to analyse the magnitude of the impact by means of level form in Turkey. In addition to this, there is a significant as well as positive impact of domestic investment on economic growth; however, there is negative and significant impact of trade liberalization on economic growth.
\end{abstract}

Keywords: foreign direct investment, gross domestic product, domestic investment, international liberalization, vector autoregression

\section{Introduction}

Foreign direct investment (FDI) is defined as broad capital flows in which a company or firm in one country expands or produces a subsidiary in another country; it contains acquisition of control and transfer of resources (Mun et al., 2008). Foreign direct investment (FDI) has a vital role on the economic growth of developing countries. It effects the employment, production, prices, income, imports, exports, general welfare of the recipient country and balance of payments. In developing countries, the FDI is the one of the vital sources of economic growth, and besides the importance of capital, FDI leads to several benefits.

The most important advantage for developing countries is FDI's contribution of bringing and introducing new technology, skills, training and other relevant as well as vital materials to their economies (Hossain \& Hossain, 2012).Additionally, the opportunity of employment is an essential advantage for the host country. When foreign firms extend to operate in their countries, they also introduce efficiency in management and higher technology production. It gives the developing countries capacity, in order to compete with foreign competitors and produce higher quality services and goods in the future. Nonetheless, the main demand for FDI comes from the need for funds for investment in developing countries. Therefore, FDI could assist them improve the standard of living and develop their countries by providing more employment and implementing strategic projects that require large funds.

According to (Nair-Reichert \& Weinhold, 2001) in the last two decades the FDI has increased by 17 percent in the developing countries. In the last twenty years, globalisation has much supported the inflows of factors of production around the world supported by the advancement of communication and information technology. Multinational companies refer to various indicators and indices in their selection of the particular developing countries to invest. Therefore, despite the advancement in the use of technology in their operation and production, these companies require higher technology and well-educated labour force. In terms of the qualified 
employment sector, developing countries are rich in labour force and population; however, they have to offer more advanced education opportunity at all levels to maintain a skilled labour force. Moreover, they must save higher amount of capital (ILGUN et al., 2010).

The remainder of the paper is organized as follows: The last part of introduction 1:2 provides an overview of FDI in Turkey. Chapter 2.1 supplies the number of models of economic growth, which are Classical growth model, Solow model, A K model and Schumpeterian growth models. The part 2 and 3 of chapter 2 which are 2.2 and 2.3 provides the theoretical and empirical results of earlier literature which is related to the impact of explanatory variable on economic growth. Chapter 3 reported methodology and analysis, in this chapter the OLS and VAR models are used with ADF and Johansen cointegration tests to show the result of relationship between GDP with FDI, DIN and TL. The last chapter is a conclusion, which is outlining the summery of the econometric result of this paper.

\subsection{An Overview of FDI in Turkey}

Turkey is a relatively open economy and growing. In 2012 the economy of Turkey was the 16th largest economy in the world, in terms of GDP by purchasing power parity for 2007 was estimated to be $\$ 1,125$ billion (International Monetary Fund, 2013). Over the period 2002-2012 Turkey shows a sturdy record of economic growth, average an annual rate of about 5.2 per cent (World Bank, 2013). After the establishment of Turkish modern state, FDI started to flow to the country and there were 94 foreign companies investing their capital in 1924. In these 94 companies, 35 of them were in trading, 12 in manufacturing industry, 23 in banking, 6 in marine fields and 11 in electricity. After 5 years, the FDI inflow increased to 30 billion dollars and the number of foreign companies rose to 114 . Government nationalized 24 foreign companies by 1928 and 25 foreign companies between 1933 and 1945 (Bildirici, 2010).

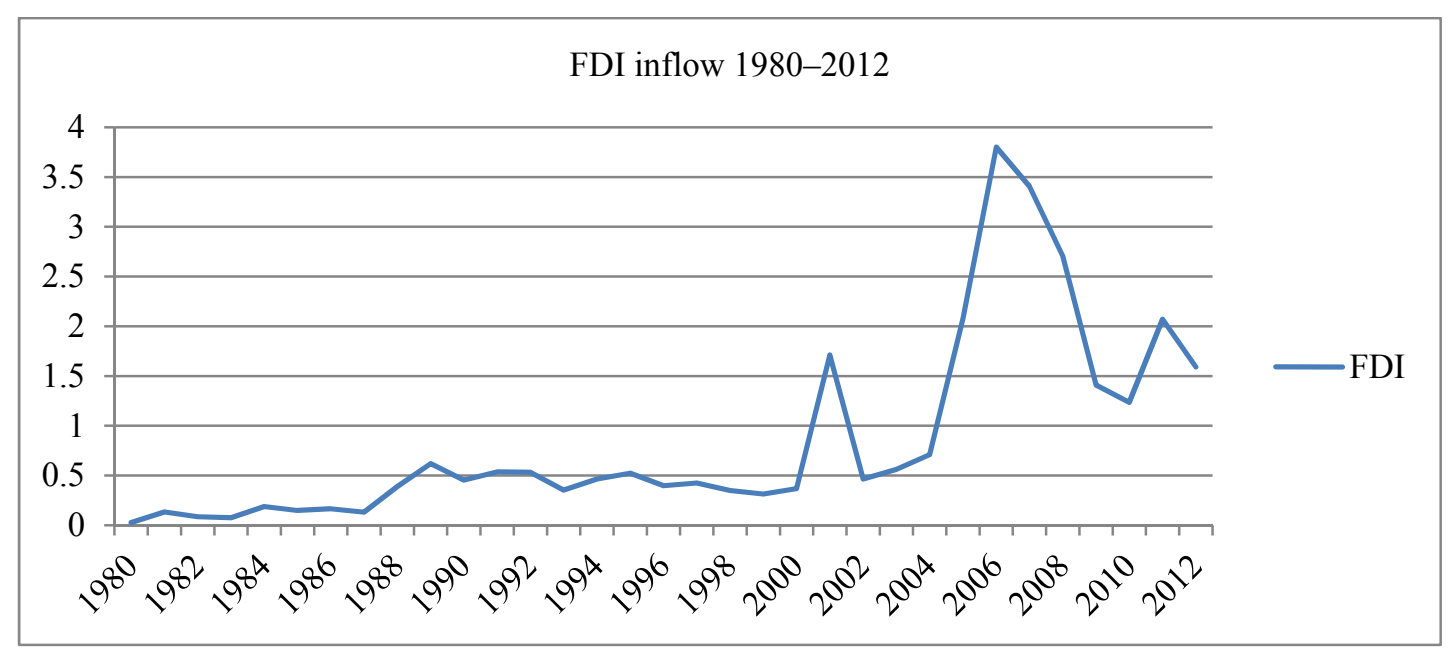

Figure 1. Percentage of FDI inflows compared GDP in Turkey between 1980-2012 (The world bank, 2013)

Prior to 1980, Turkey had put many limitations on foreign direct investment and trade. The economic policies have been changed whereby it allowed an import to export country. The move was successful particularly through new economic strategies in early 1980s. The Turkish government then introduced several economic reforms including the encouragement of FDI, the liberalization of foreign exchange market and also removed trade restrictions that helped make Turkey attractive to foreign resource and international trade (Ilgun et al., 2010). The new law of foreign investment in 2003 has a vital role to encourage the FDI, according to this law; foreign investors are not required to take official permission to invest in most sectors in Turkey (Aktar \& Ozturk, 2009). This new reform in the foreign investment law, encourages FDI inflow to Turkey, for example the total FDI was 18 million US dollars in 1980 and it reached 12,555 billion US dollars in 2012. And also, the total amount of FDI inflow to Turkey from 2003 to 2012 was 122, 811 billion US dollars. Prior to 1980, foreign direct investment inflow to Turkey was very low. This was mainly due to the government's economic policies that imposed limitation in this regard such as rationing on foreign exchange rate, quantitative restriction, high level of tariff rates and overvalued exchange rates (Saglam \& Yalta, 2009). The main areas of investment by foreign investors are in sectors such as manufacturing, services, mining and agriculture (Kiliç \& Ateû, 2009). 


\section{Literature Review}

Section one of the literature review will supply the number of models of economic growth while the second and third sections provide the theoretical and empirical review of earlier literature review which is the linkage to the impact of independent series variable on economic growth.

\subsection{Models of Economic Growth}

This section, supplies the number of models of economic growth, which are Classical growth model, Solow model, A K model and Schumpeterian growth models.

\subsubsection{Classical Growth Model}

According to Nellis and Parker (2004), the classical growth model had stemmed from the view of economists of the late 18th century and beginning of the 19th century and mainly linked to the vision and writings of Thomas Malthus. The key point of this theory is having temporary increase of growth rate in terms of countries' production which is achieved as a result of advances in technology. This model supposes that the subsistence level of wages will increase as a result of rise of real GDP per worker. This, one at a time, will result in both the rise of total supply of labour force and demonstration of total population in the country. The real wage will directly decrease with an increase of supply of labour, recurrence real GDP per worker and real income per worker return to the subsistence standard. The fundamental idea of this model is that the effect of economic growth rate originated from capital accumulation and technological change. In contrast, this theory is unsuccessful to explain the fact that new technology and farming techniques will lead to raise in the productivity of agricultural sector. Despite the increase of total population to more than 7 billion, the world has currently an abundant supply of food products.

\subsubsection{Solow Model}

Solow growth model is thoroughly related to the improvement of the neoclassical growth model by Swan and Solow (1956). According to their contributions, growth is predominantly explicated by the accumulation of labour and physical capital (Neuhaus, 2006). In general, this model concentrates on four variables: capital (K), knowledge (A), output, $(\mathrm{Y})$ and labour $(\mathrm{L})$. Whenever, in any economy, output is produced as a result of combination from some amounts of knowledge, labour and capital. The consideration of this model is that saving rate is most prospective affected by policy. According to Solow model, the division of its incomes between borrowing and taxes and also its taxes behaviours of investment and saving, and the government's purchases division between investment and consumption goods are completely possible to create impact on the saving rate changing. This model further suggests that the economy's balanced growth path changed due to level effect of change in the saving rate. In sum, according to this model, the growth effects obtained only whenever change in the level of technological progress, while all further changes have level effects without growth effect (Romer, 2012).

\subsubsection{AK Model}

The first wave of endogenous growth model is the AK model. According to the neoclassical growth model, the growth appears exogenously through functions of production. On the contrary, in the AK model, growth rate is supposed to be endogenous. In addition, a fundamental expectation of the endogenous model is that there is long run growth rate positively affected by investment and saving rates (Sørensen \& Whitta-Jacobsen, 2005). This model describes that change in a country's policies, for instance capital investment or subsides to research to have no long run effect but only have level impacts. Furthermore, according to AK model these policies increase the growth rate momentarily, and the growth rate returns in the long run to its original level. On the other hand, this model proposes that there is a positive long run impact on growth rate due to large amount level of investment in defined capital ( $\mathrm{Li}, 2002)$. According to (McGrattan, 1998) the simple AK model shows the relation between growth rate and investment rates as predicted. In spite of that, simplest versions of this model indicate that there is a positive link between growth rate of output and share investment of output.

\subsubsection{Schumpeterian Growth Models}

Schumpeterian growth models gather specific kind of economic growth models, which are produced by the endogenous process innovation and introduction of product. The "Schumpeterian growth" term honours the name of Joseph Schumpeter, who defined the progress of capitalism via creative process. Schumpeterian growth models are nearer in essence to Schumpeter's thinking than other those that put emphasis on learning by doing, physical capital accumulation and human capital accumulation as foundations of growth process in the economy (Dinopoulos, 2006).The Schumpeterian model of growth has the natural property that neoteric discovery make products obsolete and old technologies. In addition, this creative obliteration lineament in sequence has both 
normative and positive consequences. On the normative side, in case of development and future research that recent innovation has positive externalities. In case of positive side, it suggests a negative link between future and current body of research, which emerges in the presence of matchless in the likelihood of cyclical patterns of growth and also balances the growth equilibrium (Aghion et al., 1998).

Previous Schumpeterian growth models had analyzed the link between long run growth and trade patterns by using a variety of approaches. They produced product cycle trade that is constructed on the observation which many goods are discovered in the developed countries and their manufacture shifts to developing countries as they are in the low level of technology and they have imitated in this case. Moreover, the determinants of growth rate examined by this model had also analyzed Schumpeterian models in open economies. According to Prior endogenous growth models, there are three comprehensive channels which convey from the impact of openness policy with regard to economic sector to long run growth. First channel is trade, the long run rate of growth and innovation as well as the profitability of R\&D investment increase due to increasing of the size of the market. Secondly, economic openness, through simplifying the information exchange, raises the productivity of researchers and the field of knowledge spillovers. Thirdly, there is the trade openness (Dinopoulos, 2006).

\subsection{Theoretical Framework}

A number of studies have empirically and theoretically estimated the procedure in which inflow FDI may participate to the economic growth of the host countries. According to Zhang (2001) FDI could enhance economic growth of the host country via spillover effect and direct effect. He also argues that both economic growth and FDI are positively interdependent. The rapid growth of FDI makes positive effect on economic growth which normally leads to increase productivity as a result of their extra facilities through achieving managerial skills and better technologies from foreign countries. Most importantly, FDI is expected to be growth enhancing by human capital and technological change and it further infers increasing productivity through acquisition promoted and labour training endorsed by transnational corporations (Buckley et al., 2002).

In the same way, Althukorala (2003) finds that FDI offers for developing countries abundant required resources such as technology, capital and entrepreneurial abilities which are required to decrease poverty, create new jobs and industrialise the developing countries. The extent to which FDI influences the growth is nevertheless based on the quality of economic and social environment of host countries. This quality of economic and social environments relates to the level of technological growth, the host countries savings rate and the degree of openness in the host country. The host country will benefit from rising FDI to their economic growth when they have high technological progress, high rate of savings and open trade system (Akinlo, 2004). Consequently, (Zhao \& Du, 2007) maintain that fast economic growth usually provides extreme level of capital gap in host countries; it may henceforth demand more FDI through providing encouraging terms in order to attract foreign investors since FDI is a source of capital. Importantly, a high level of economic growth in the developing countries will build confidence and encourage overseas investors to invest in their countries.

Despite this, FDI via capital accumulation in the beneficiary economies may impact growth in host economies for the reason that FDI is parallel to host investment and also FDI is probable to produce non-convex growth through boosting the combination of foreign technologies and new inputs in the fabrication occupation of the recipient economy. According to Adams (2009) there are two main theoretical viewpoints that have been used to demonstrate the influences of FDI on developing countries such as the economies of host countries. The two theoretical viewpoints are dependency and modernization theories. The dependency theorists claim that the foreign investment expected to have adverse effect on distribution of income and economic growth. Recommence study interests in foreign direct investment stalks from the viewpoints change in the midst of policy makers from animosity to conscious encouragement, especially included in developing countries.

On the other hand, modernization theories depend on the endogenous growth and neoclassical theories. They propose that FDI is expected to have positive effects on economic growth in host countries that economic growth is in need capital investment. The developing countries could also earn new technology through FDI which is important to promote all economic sectors that is required for innovation to promote economic growth (Adams, 2009). Likewise, Ilgun and et al. (2010) claim that nearly all studies support positive association between FDI and economic growth. It is worth mentioning that when the country is growing promptly it may lead foreign investors to be more motivated to taking participate in the growing of output. According to Razin and Sadka (2012), unregulated foreign investment may offer a number of advantages. Firstly, foreign investments decrease the risks in terms of owners of capital by permitting them to diversify their investments and lending. Secondly, the international integral of capital markets may participate in the prevalence of best practice in accounting standards, legal tradition and corporate governance. Thirdly, the countries' capacity to pursue bad policies could 
be limited by the global mobility of capital.

Similarly, the FDI leads to increase the accumulation of capital in the developing countries that enhances the efficiency of host country firms through demonstration of effects and contract, and their experience to strong competition. The rapid growth of FDI inflows of the developing countries demands an analysis of the impact on economic output. This is because the increase of FDI inflows makes huge impact on local economic growth and their productivity due to their extra facilities by using better technologies and managerial skills. Therefore, the impact of FDI on economic output is vast (Hossain \& Hossain, 2012).In brief, most writers referred to in the previous section give the impression that economic growth is increased through FDI via efficiency and productivity. As a result, increase in the level of economic growth in the host countries would offer better investment environments for foreign investors, therefore; there is positively interdependent correlation between FDI and economic growth and may lead to a two-way causality.

\subsection{Empirical Framework}

An empirical study by Borensztein and et al. (1998) examines the impact of FDI on economic growth rate in cases of 69 developing countries over the period of 1970-1989. The results of this study reveal a positive relationship between FDI and economic growth only when the host country has satisfactory absorptive competence and high level of educational sectors for progressive technologies. Further, the other significant finding of this study is that the domestic investment is participating less than FDI in terms of promoting economic growth. Furthermore, the study indicates that the overall economic growth rate is positively affected by FDI. Nevertheless, for those countries which have low level of education sectors and low level of human capital their growth rate is negatively related with FDI. Zhang (2001)analyses the impacts of FDI on economic growth rate of China, over the period 1984-1998 using a cross-section data, panel data and growth model. The result of the study shows that the foreign direct investments appear to support China's economic growth. The study also finds that FDI seems to participate in income growth in China via positive externality effect such as: dispersing technology and facilitating evolution and also via direct effects such as boosting exports and increasing productivity.

Another empirical study by Ozturk and Kalyoncu (2007) maintains the impacts of FDI on economic growth in both Turkey and Pakistan over the periods of 1975-2004 by using Granger causality and Engle-Granger cointegration tests. The result of the study shows that there is a positive causality relationship between FDI and economic growth in the cause of Turkey whereas there is only economic growth that causes foreign direct investment in the case of Pakistan. Baharumshah and Almasaied (2009) explore the impact of foreign direct investment on economic growth in Malaysia in timeframe between 1974 and 2004 including the economic crises of 1997. It is designed to find out the long-run relationship between FDI and economic growth of Malaysia by using the tests (BT) procedure. This study finds that economic growth rates can be affected by FDI, domestic capital formation, financial deepening and human capital.

In addition, it discovers suitably controlling for other drivers of economic growth such as exportation, domestic investment and human capital. According to this study, economic growth is significantly affected by FDI; however, the FDI's effect is less visible than the effect of domestic investment on economic growth. On the other hand, FDI is predominantly the essential channel in order to transfer advanced technology to Malaysia's developing economy. The development of education system and financial sector likewise permit Malaysia to increasingly obtain from the spillover impact of FDI.

Another empirical study conducted by Balamurali and Bogahawatte (2004) utilises the Engle and Granger error correction approach in order to consider the causality and long run and short run relationship between economic growth and foreign direct investment of Seri Lanka over the period of 1977-2003. This case study finds that economic growth rates are significantly affected by foreign direct investment; the result indicates that there is bidirectional causality between economic growth and FDI. Moreover, it shows that there is a low level of investment in Seri Lanka as a result of several reasons such as low investment of human resource, the low level of growing infrastructure sector, high lending rate, transportation and instability in terms of political environment.

Agrawal and Khan (2011) use linear multiple regression model covering the period of 17 years from 1993-2009. This study examines the impact of foreign direct investment on economic growth rate of India and China. They use growth model and include a number of factors in this model which are gross capital formation, FDI, human capital, GDP and labour force. Subsequently, they use Ordinary Least Square method and they find $0.02 \%$ rise in GDP of India and $0.07 \%$ rise in GDP of China as a result of $1 \%$ rise in FDI. Further, this study finds that the economic growth in India is less affected by FDI than China, since the later can utilize FDI better than India. 
Umoh et al. (2012) investigate the empirical relationship between economic growth rate and FDI in Nigeria between 1970 and 2008. In order to examine this relationship, they use simultaneous and single equation systems. Their results suggest that there is a positive causal from growth rate to FDI and from FDI to growth rate. Additionally, the result acquired demonstration that economic growth rate in Nigeria and FDI inflow are jointly determined. According to this analysis, the increasing private contribution and superior openness are main causes that can obtain higher economic growth rates and to attract more foreign direct investments to flow into Nigeria.

It is important to mention that another empirical study by Arısoy (2012) goes through the effects of FDI on total factor productivities and economic growth for Turkey for the period 1960-2005. The empirical results reveal that FDI positively participates in economic growth rate and total factor productivities through technological spillovers and capital accumulations.

To summarize, it could be noticed that a number of studies are conducted to investigate the relationship between FDI with economic growth, exportation, labour force, capital accumulation, advanced technologies, skills and economic policy. The majority of these studies suggest a positive relationship between FDI and economic growth in developing countries. Panel data analysis and time series regression are used by numerous of these studies in order to provide and explain the correlation between economic growth and FDI. In addition to this, the majority of them have used GDP per capital for economic growth.

\section{Methodology and Analysis}

There are a number of studies that have been conducted on the relationship between FDI and economic growth in the case of Turkey. A difference between this study and the previous ones is that other studies include data up to 2009 , which makes this study more up-to-date than earlier ones. The data for this paper are annual figures that cover over the period between 1980-2012 in order to examine cointegration relationship between GDP and FDI in the long run for the case of Turkey. It would have been more valuable to use monthly or quarterly data due to rise the number of observations in the study, nevertheless, quarterly and monthly data do not exist for most variables. The dependent variable of the study is gross domestic product (GDP) and the independent variables are foreign direct investment (FDI), domestic investment (DIN), and trade liberalization (TL) which is combination of export and import. Also, the data is taken from World Bank Development Indicators. This study examines the relationship between economic growth and FDI and it also follows Athukorala (2003)'s study which is based on the following equation:

$$
Y=f(F D I, D I N, T L)
$$

In the equation, Y, FDI, DIN and TR denote output, the amount of FDI, domestic investment and trade liberalization. Additionally, in this study the OLS and Vector Autoregression model (VAR) is employed in order to estimate the casual linkage between foreign direct investment and economic growth and it is analyzed by using the following econometric equation.

$$
\log G D P=\alpha+\beta_{1} F D I+\beta_{2} D I N+\beta_{3} T L+\varepsilon
$$

In general, the study examines the following hypothesis: Do FDI inflows cause economic growth in Turkey?

Table 1. Dependent and independent variables

\begin{tabular}{lllllll}
\hline Variable & Measuring & Source & Minimum & Maximum & Mean & Std. Dev. \\
\hline GDP & GDP per capita (current US\$)Dependent Variable & World Bank & 1246.2 & 10666. & 4324.1 & 3127.7 \\
FDI & $\begin{array}{l}\text { Foreign Direct Investment FDI inflows } \\
\text { (Annual \% of GDP). Independent variable }\end{array}$ & & & 3.8020 & 0.86122 & 0.97252 \\
& $\begin{array}{l}\text { Domestic Investment (Gross fixed capital Bank } \\
\text { DIN }\end{array}$ & World Bank & 14.395 & 26.420 & 20.371 & 0.97252 \\
& $\begin{array}{l}\text { formation (\% of GDP)) Independent variable } \\
\text { Trade Liberalization (export + import). }\end{array}$ & World Bank & 17.089 & 56.391 & 40.625 & 10.349 \\
& Independent variable & & & & & \\
\hline
\end{tabular}

\subsection{Ordinary Least Square Regression}

The key idea of the Ordinary Least Square regression is that employing this model in order to estimate the coefficients and intercept through minimizing the sum of squared estimate errors in the multiple regression models (Murray, 2006). 
The Ordinary Least Squares regression analysis employs the level series in equation 1.

Table 2. OLS regression in the level form

\begin{tabular}{lllll}
\hline \multicolumn{5}{l}{ Ordinary Least Squares regression in the Level form } \\
& coefficient & std. error & t-ratio & p-value \\
\hline Constant & 7.41297 & 1.82403 & 4.064 & $0.0003 * * *$ \\
1_FDI & 0.435257 & 0.0989606 & 4.398 & $0.0001 * * *$ \\
1_DIN & -0.197327 & 0.374819 & -0.5265 & 0.6026 \\
1_TL & 0.444244 & 0.395522 & 1.123 & 0.2706 \\
L_GDP $=7.41297+0.435257$ FDI - 0.197327 DIN + 0.444244 TL \\
Observations (33)
\end{tabular}

Table number 2 shows that the coefficient of 1 FDI is 0.435257 , which indicates $1 \%$ rise in FDI would result in $0.4 \%$ increase in GDP of Turkey; this result further indicates that there is short-term positive relationship between GDP and FDI. And also, the coefficient of DIN is -0.197327 which implies a negative short-term relationship between GDP and DIN, which means that a1\% rise in DIN, would result in -0.197327 decrease in GDP. Additionally, the p-value of DIN is not significant that is consequently higher than $05 \%$. In contrast, the coefficient of TL is 0.444244 , which shows a positive and insignificant linkage between GDP and TL in the case of Turkey. On the other hand, when Ordinary Least Squares regression analysis is employed the first difference series could be found in equation 2 :

Table 3. OLS regression in the first difference form

\begin{tabular}{lllll}
\hline \multicolumn{5}{l}{ Ordinary Least Squares regression in the First difference form } \\
& coefficient & std. error & t-ratio & p-value \\
\hline Constant & 0.0843855 & 0.0201416 & 4.190 & $0.0005^{* * *}$ \\
d_1_FDI & 0.0274152 & 0.0272031 & 1.008 & 0.4662 \\
d_1_DIN & 0.687336 & 0.222919 & 3.083 & $0.0046^{* * *}$ \\
d_1_TL & -0.925464 & 0.209226 & -4.423 & $0.0001^{* * *}$ \\
d_L GDP $=0.0843855+0.0274152$ FDI +0.687336 DIN - 0.925464 TL \\
Observations (33) \\
\hline \multicolumn{5}{r}{ R-squared $=0.533216$} \\
\hline
\end{tabular}

According to the table number 2 ,the coefficient of the first difference of FDI is 0.0274152 , which shows that $1 \%$ rise in FDI would result in $0.027 \%$ increase in GDP of Turkey; also this result illustrates a short-term positive relationship between FDI and GDP. Additionally, the coefficient of first difference of DIN is 0.687336 which shows that there is a positive short-term relationship between DIN and GDP, which means that a $1 \%$ rise in DIN may result in 0.687336 increases in GDP. In addition, the p-value of DIN is significant which consequently less than $05 \%$. On the contrary, the coefficient of TL is -0.925464 , which indicates that there is a negative and significant short run relationship between TL and GDP in the case of Turkey. To summarize, According to the third table there is insignificant but positive short run relationship between GDP and FDI in terms of first difference, and there is also a significant and positive short run relationship between DIN and GDP. Conversely, there is a negative, yet significant, short run relationship between TL and GDP.

\subsection{Augmented Dickey Fuller Test}

The most commonly employed test of the unit root in time-series is the Augmented Dickey Fuller (ADF) test. On the other hand, the test p-values or a critical value for dissimilar small sample size has to be estimated asymptotically through simulation techniques (Hsiao \& Hsiao, 2006). Because of including the vital effect of time series, all data are stated in logarithms, represented by L preceding the respective variables name. When these variables share the first different and common stochastic trend they are stationary though they have to be cointegrated. In addition, in econometrics studies the use of first differences simplifies the results analysis, subsequently the rate of change of initial variables represented by the first differences of logarithms of these variables. The ADF unit root test is used due to the analysis of the multivariate time series and also for intention to prepare evidence about when the variables are integrated (Dritsaki et al., 2004).

In addition, Dickey and Fuller (1979) illuminated that the null hypothesis representing a unit root can be rejected 
when the series is stationary, despite the fact that the null hypothesis representing a unit root cannot be rejected if the series is non-stationary. Therefore, we have to take the first difference or greater differencing due to eradicate the unit root. Additionally, the stochastic properties of the series will be tested due to avoid estimating spurious regression. One of the main measures is the Augmented Dickey-Fuller (ADF) test. In The Augmented Dickey-Fuller test that the series are non-stationary, the test depends on rejecting a null hypothesis of unit root. The following regression states the common form of the Augmented Dickey-Fuller test.

$$
\Delta X_{t}=a_{0}+a_{1} X_{t-1}+\sum_{i=1}^{n} a_{1} \Delta X_{i}+\delta_{t}+\varepsilon_{t}
$$

Where $\Delta X_{t}$ is commonly called the first difference, $X_{t}$ denotes a liner time trend and it is a time series, $a_{0}$ denotes a constant, $\mathrm{n}$ denotes the optimum number of lags and $\varepsilon_{\mathrm{t}}$ is the error term (Imoudu, 2012).

Table 4. Unit root test

\begin{tabular}{|c|c|c|c|c|c|c|c|}
\hline \multirow{3}{*}{ Variables } & \multirow{3}{*}{$\begin{array}{l}\text { Level and first } \\
\text { Difference }\end{array}$} & \multicolumn{6}{|c|}{ Augmented Dickey Fuller Statistics (ADF) test } \\
\hline & & \multirow[t]{2}{*}{ ADF T-statistic } & \multicolumn{2}{|c|}{ Critical Value With Constant } & \multirow{2}{*}{$\begin{array}{l}\text { ADF } \\
\text { T-statistic }\end{array}$} & \multicolumn{2}{|c|}{$\begin{array}{l}\text { Critical Value } \\
\text { With Constant and tren }\end{array}$} \\
\hline & & & $1 \%$ & $5 \%$ & & $1 \%$ & $5 \%$ \\
\hline \multirow{2}{*}{ Log GDP } & Level & 0.166077 & -3.6537 & -2.9571 & -3.05451 & -4.2350 & -3.5403 \\
\hline & $1^{\text {st }}$ Difference & -4.3453 & -3.6329 & -2.9484 & -4.24451 & -4.2436 & -3.5443 \\
\hline \multirow{2}{*}{ Log FDI } & Level & -1.17115 & -3.6537 & -2.9571 & -1.99389 & -4.2350 & -3.5403 \\
\hline & 1st Difference & -7.52237 & -3.6329 & -2.9484 & -7.3858 & -4.2436 & -3.5443 \\
\hline \multirow{2}{*}{ Log DIN } & Level & -1.9818 & -3.6537 & -2.9571 & -1.88681 & -4.2350 & -3.5403 \\
\hline & 1st Difference & -4.81926 & -3.6329 & -2.9484 & -4.79498 & -4.2436 & -3.5443 \\
\hline \multirow{2}{*}{$\log T L$} & Level & -1.04969 & -3.6537 & -2.9571 & -2.17646 & -4.2350 & -3.5403 \\
\hline & 1st Difference & -4.84832 & -3.6329 & -2.9484 & -4.85165 & -4.2436 & -3.5443 \\
\hline
\end{tabular}

ADF test is used in order to test non-stationarity and stationarity for all variables, which are log of GDP (LGDP), Log of FDI (LFDI), Log of DIN (LDIN) and Log of TP (LTP), and to examine the variables nature as I(0) or $\mathrm{I}(1)$.

Table number 1 illustrates the ADF results with intercept as well as intercept and trend. As it can be seen that the data series for all variables at level contain unit root, therefore we fail to reject the null hypothesis as a result which is non-stationary but when we take the first difference, all the series become stationary at 5 percentage confidence levels.

In the level form and with constant, ADF test shows that, the value of ADF statistics of series LGDP is $(-0.166077)$,as it can be seen that it is greater than the critical values at $5 \%(-2.9571)$ and $1 \%(-3.6537)$ significance levels. Similarly, with constant and trend in the level form ADF value of series LGDP (-3.05451) is higher than the critical values at 5\% (-3.5403) and 1\% (-4.2350) significance levels. For this reason, null hypothesis cannot be rejected; this means series is not stationary and LGDP has a unit root problem in both with constant and with constant and trend.

Conversely, the ADF statistics value in the first difference of LGDP with constant is (-4.3453) and with constant and trend (-4.24451), which are lesser than the critical values at the same significance levels. As a result, for the series of LGDP, null hypothesis is rejected. Additionally, ADF statistics values of series LFDI in the level form with constant is higher than critical value in terms of 5\% significance levels. Similarly, ADF statistics values of series LFDI in the level form with constant and trend is (-1.99389) which is smaller than critical value at $5 \%$ significance levels, ADF test statistics values, with first difference of both constant \& constant and trend of series LFDI $(-7.52237,-7.3858)$ that are much smaller than the critical values at the same significance levels. This consequence shows that the null hypothesis can be rejected and the series of LGDP has not any unit root problem.

In the same way, in terms of the level form with both Constant \& constant and intercept, ADF statistics values of series LDIN are (-1.9818) with constant while they are (-1.88681) with constant and trend that are higher than the critical values at $1 \%$, and $5 \%$ significance levels. As a result, LDIN has unit root problem and null hypothesis which cannot be rejected. This shows that the series of LDIN is not stationery in this significant level. Alternatively, the first difference ADF test statistics values are lesser than the critical values at the same significant levels of the series with constant and with constant \& trend. Consequently, the series of LDIN is stationary and the null hypothesis can be rejected. On the contrary, ADF t-statistics value of the series of LTL in 
the level form is higher than critical values at $5 \%$ significance levels with both constant and with constant and trend. This means that the series of LTP is non-stationary and null hypothesis cannot be rejected. To sum up, this paper's result demonstrates that all variables are non-stationary in level but in first-differences become stationary. This means that all variables show integrated order one.

\subsection{Co-Integration Test}

Cointegration is defined when more than one series variable share a common stochastic trend. According to Studenmund (2006) when the long run equilibrium relationship occurs between a number of variables, it could be said as cointegrated. Cointegration is a statistical explanation between unstable variables in terms of long run relationship between them. Furthermore, it is the prerequisite for building causality regression of variables. Nevertheless, due to the issue of incorrect regression, we cannot employ classical regression model for a lot of unstable variables to make analysis. The presence of certain long run equilibrium relationship between some unstable variables was confirmed by economic theories. This equilibrium designates that there is not an interior instrument destroying the stability in an economic system. This test is employed in order to detect whether there is a long run relationship between economic variables (Sun, 2011). This paper elaborates on Johansen Test for using multivariable, instead of Angle Granger cointegration test which targets at demonstrating the cointegration between two variables. We proceed to test cointegration; following this we establish the order of the individual series for all the variables. In this case, we use the following cointegration regression:

$$
G D P_{t}=a_{1}+a_{11} F D I_{t-1}+a_{12} D I N_{t-1}+a_{13} T L_{t-1}+e_{t}
$$

The null hypothesis in this test is that no variable is cointegrated. If the probability value of trace test is less than $5 \%$ percentage significant level, then we reject null hypothesis which means that there is a cointegration between variables. In contrast, according to this test, when probability value is greater than $05 \%$ for trace value tests, then we fail to reject null hypothesis. In this case there is no cointegration between the variables (Granger, 1969).

\subsubsection{Optimal Lag Order}

In order to establish optimum lag length, this paper uses maximum likelihood tests. Under this result, the lag one is the optimum lag length, as a result of the BIC value of first lag is the smallest value.

Table 5. Optimal lag order

Maximum lag order 5

The asterisks below indicate the best (that is, minimized) values of the respective information criteria,

$\mathrm{AIC}=$ Akaike criterion, $\mathrm{BIC}=$ Schwarz Bayesian criterion and HQC $=$ Hannan-Quinn criterion.

\begin{tabular}{cccccc}
\hline Lags & $\operatorname{loglik}$ & $\mathrm{p}(\mathrm{LR})$ & $\mathrm{AIC}$ & $\mathrm{BIC}$ & $\mathrm{HQC}$ \\
\hline 1 & 57.25809 & & -2.759858 & $-1.799979^{*}$ & -2.474436 \\
2 & 66.32528 & 0.31609 & 2.246317 & 0.518534 & 1.732556 \\
3 & 82.32761 & 0.00999 & -2.246490 & 0.249196 & 1.504391 \\
4 & 101.49922 & 0.00135 & 2.481424 & 0.782165 & 1.510988 \\
5 & 156.80550 & 0.00000 & $5.393000^{*}$ & 1.361507 & $4.194226^{*}$ \\
\hline
\end{tabular}

\subsubsection{Johansen Test}

The two Johansen tests for cointegration or for long run equilibrium relationship between variables are used to establish the number of cointegrating vectors or the rank of $\beta$. These are the trace test for joint hypothesis and the $\lambda$-max test for hypothesis on individual eigenvalues.

The term of individual eigenvalues is associated to the distance between the set of singular matrices and a matrix. According to Murray (2006) the Trace test is a test employed in testing the null hypothesis in terms of the Johansen cointegration test.

$$
\lambda_{\text {trace }}(r)=-T=\sum_{i=r+1}^{g} \ln \left(1-\lambda_{i}\right)
$$

And

$$
\lambda_{\max }(r, r+1)=-T \ln \left(1-\lambda_{r+1}\right)
$$

Where $\lambda_{\mathrm{i}}$ is the value estimation for the ith ordered eigenvalue from the matrix of $\Pi$. And $r$ denotes the number of cointegrating vectors under the hypothesis. Naturally, the greater is $\lambda_{\mathrm{i}}$, the more negative and the larger will be $\ln \left(1-\lambda_{\mathbf{i}}\right)$ and therefore, the t-statistic will be the greater. A different cointegration vectors associated with each eigenvalue. A significant cointegration vector occurs when the eigenvalue significantly is none-zero. The joint 
test is the $\lambda_{\text {trace }}$ test where the null hypothesis is equal or less than $\mathbf{r}$ whereas general or an unspecified alternative is greater than $\mathbf{r}$. it begins with $p$ eigenvalues, and at that point successively the highest is removed. $\lambda_{\text {trace }}$ is equal to zero when all the $\lambda_{\mathbf{i}}$ are equal to zero for $\mathrm{i}=1 \ldots \mathrm{g}$. the $\lambda_{\max }$ conducts differ tests on all eigenvalues, and also has as its hypothesis that the number of cointegrating vectors is $r$ in contradiction of an alternative of $r+1$ for $\lambda_{\text {trace }}$.

According to the null hypothesis for $\lambda_{\max }$ test there is no cointegrating vectors and corresponding to $\Pi$ that having zero rank. If this null hypothesis is accepted, it would be indicated that the testing would be completed and there are no cointegrating vector. Conversely, if $\mathrm{H} 0$ : $\mathrm{r}=0$ not accepted the null hypothesis that is concluded that there is one cointegrating vector. Thus the value of $r$ rise continuously until the null hypothesis is no longer rejected (Brooks, 2008).

In addition, the Johansen test assumes that the eigenvalues $\lambda_{i}$ are arranged from the biggest to the smallest. The hypothesis for L-max test is that $\lambda_{i=} 0$. Instead of this hypothesis, the trace test corresponding considers that the hypothesis $\lambda_{\mathrm{j}=} 0$ for all $\mathrm{j} \geq \mathrm{i}$ (Cottrell \& Lucchetti, 2012). According to Johansen test, if the calculate value of trace test was smaller than the critical value of $\lambda$-trace test, then the restriction would not bind and also the variables would not cointegrated, respectively (Enders, 2008). Additionally, if the t-statistic is higher than critical value, then it rejects the null hypothesis.

Table 6. Result of the Johansen test

\begin{tabular}{|c|c|c|c|c|c|}
\hline \multicolumn{6}{|c|}{ The Johansen test } \\
\hline Rank & Eigenvalue & Trace test & p-value & Lmax test & p-value \\
\hline 0 & 0.55007 & 38.731 & {$[0.2743]$} & 25.557 & {$[0.0877]$} \\
\hline 1 & 0.25050 & 13.174 & [0.8816] & 9.2274 & [0.8116] \\
\hline 2 & 0.10618 & 3.9463 & [0.9013] & 3.5922 & [0.8909] \\
\hline 3 & 0.011005 & 0.35412 & {$[0.5518]$} & 0.35412 & {$[0.5518]$} \\
\hline
\end{tabular}

Accordig to the Johansen Cointegration test, there is evidence for cointegrating relationship, if the critical value is smaller than trace test value or if the probability value is smaller than the $5 \%$ percentage significant level. For instance, if one p-value is smaller than $5 \%$ significance level, then the cointegration rank is one. Similarly, if two of the p-values are smaller than 5\% significant level, then the cointegration rank is two and so on. Table number 6 indicates that there is no cointegrating between variables in terms of the evidence of Johansen Cointegration test.

According to this table, all four probabilty values are higher than $5 \%$ significant level, which are $0.2743,0.8816$, 0.9013 and 0.5518 respectively in terms of Trace test and also the probability value of Lmax test is 0.0877 , $0.8116,0.8909$ and 0.5518 respectively. Additionally, all four probability values interms of Trace test and Lmax test indicates that there is no long run equilibrium relationship between GDP, FDI, DIN and TL. And also, the cointegration rank of this cointegration is zero due to the p-values are higher than $5 \%$ percentage significant level. Therefore, it is concluded that as a result of the co-movement among the four variables GDP, FDI, DIN and TL, there is no long run linkage between them in Turkey over the period of 1980-2012.

\subsubsection{Vector Auto Regressive Model (VAR)}

The Vector Autoregression (VAR) model is one of the most flexible and effective models for the examination of multivariate time series. The VAR model was presented into practical econometrics by Sims (1980). It is a natural generalisation and an addition of the nivariate autoregressive model to dynamic multivariate time series. The vector autoregression (VAR) model has confirmed to be very valuable for forecasting and for describing the dynamic behaviour of economic variables and financial time series and for forecasting. It often offers better forecasts than those from univariate time series models.

In general, the VAR models can be made conditional on potential future paths of specified variables and are often seen to provide a more flexible forecast. Additionally, in order to provide data description and forecasting, the VAR model could be employed for policy analysis and structural inference. Typically, the imposition convinced assumption about the causal structure of the data under investigation is vital to summarize the causal effects of innovations and unforeseen shocks on the variables in the model.

These causal influences are typically shortened with impulse reaction forecast error variance decompositions and forecast error variance decompositions functions. Let $Y_{t}=y_{1 t}$ denote an $(n \times 1)$ vector of time series variables. 
The basic n-lag vector autoregressive (VAR (n)) model has the form:

$$
Y_{t}=c+\Pi_{1} Y_{t-1}+\Pi_{2} Y_{t-2}+\Pi_{3} Y_{t-3}+\ldots+\Pi_{n} Y_{t-n}+\varepsilon_{t}, \quad t=1,2, \ldots, T
$$

Where $\Pi_{\mathrm{i}}$ are $(\mathrm{n} \times \mathrm{n})$ coefficient matrices and $\varepsilon \mathrm{t}$ is an $(\mathrm{n} \times 1)$ unobservable zero mean white noise vector process (serially uncorrelated or independent) with time invariant covariance matrix $\Sigma$. A generalised multivariate vector auto regression model for the four variables in respect of gross domestic product, foreign direct investment, domestic investment and trade liberalization is as follows:

$$
\begin{aligned}
d G D P & =c_{1}+\beta_{11}^{l} d G D P_{t-1}+\beta_{12}^{l} d F D I_{t-1}+\beta_{13}^{l} d D I N_{t-1}+\beta_{14}^{l} d T L_{t-1}+\varepsilon_{1 t} \\
d F D I & =c_{2}+\beta_{21}^{l} d G D P_{t-1}+\beta_{22}^{l} d F D I_{t-1}+\beta_{23}^{l} d D I N_{t-1}+\beta_{24}^{l} d T L_{t-1}+\varepsilon_{2 t} \\
d D I N & =c_{3}+\beta_{31}^{1} d G D P_{t-1}+\beta_{32}^{l} d F D I_{t-1}+\beta_{33}^{l} d D I N_{t-1}+\beta_{34}^{l} d T L_{t-1}+\varepsilon_{3 t} \\
d T L & =c_{4}+\beta_{41}^{l} d G D P_{t-1}+\beta_{42}^{l} d F D I_{t-1}+\beta_{43}^{l} d D I N_{t-1}+\beta_{44}^{l} d T L_{t-1}+\varepsilon_{4 t}
\end{aligned}
$$

According to (Wooldridge, 2009), four equations could be established while having four series. At the same time, there is an error term (as illustrated in this paper) in each equation such as in equations 6, 7, 8 and 9, furthermore, the (d) denotes the first difference of variable, therefore, this means that there is a difference between GDP and dGDP. Additionally, the word Vector comes from their own past, in general, it could use past values in order to predict future of variables in terms of Vector Autoregression model.

\subsubsection{Granger Causality Test}

The co-integration test confirms the long-term equilibrium relationship between variables. In addition, it will determine the form of the relationship. According to Studenmund (2006), Granger causality is a circumstance in which one series consistently changes before another series variable, and also testing for causality in both ways or directions through testing the hypothesis, if the F-statistic is significant, then the granger cause exist. Additionally, this test is crucial, because it gives us opportunity to analyse which series leads to the other series, as well as, such leading series variables are enormously beneficial for estimating purpose. The hypothesis of Granger causality is tested by the VAR model.

Table 7. Result of Granger causality test

\begin{tabular}{lllll}
\hline Null Hypothesis: & Lag & F-Statistic & Prob. & Conclusion (Hypothesis) \\
\hline GDP does not Granger Cause FDI & 1 & 0.098796 & 0.7558 & Fail to reject \\
FDI does not Granger Cause GDP & 1 & 0.64491 & 0.4292 & Fail to reject \\
GDP does not Granger Cause DIN & 1 & 2.6832 & 0.1135 & Fail to reject \\
DIN does not Granger Cause GDP & 1 & 0.24407 & 0.6254 & Fail to reject \\
GDP does not Granger Cause TL & 1 & 0.27114 & 0.6070 & Fail to reject \\
TL does not Granger Cause GDP & 5 & 2.9332 & 0.0987 & Rejected in 10\% significant level \\
d_1_FDI =0.0868474 + 0.0402679 FDI + 0.115165 DIN - 0.413250 TL & & \\
\hline
\end{tabular}

The table number 3 stated the causality test result between GDP as a dependent variable with all three variables FDI, DIN and TL, by using the VAR model. The probability values for six F-statistics are put on the right side of this table. If the probability values are higher than any level, then the null hypothesis cannot be rejected. On the other hand, if it is less than any another level the null hypothesis would be rejected. This paper finds no causality between GDP and FDI.

Additionally, GDP does not Granger cause with DIN; as a result the null hypothesis is accepted. Similarly, DIN does not Granger cause with GDP, because the null hypothesis cannot be rejected. Additionally, GDP does not imply Granger Cause with TL, due to the null hypothesis which cannot be rejected. On the other hand, the result also shows that TL Granger cause with GDP because it can reject the hypothesis at $10 \%$ significance level. Further to this, the equation of table number 4 indicates that the FDI and DIN have positive and insignificant impact of GDP. On the contrary, TL has negative and insignificant effect on GDP.

\subsection{Difference between the Result of VAR and OLS Regression}

According to the result of VAR model, there is no causality and long run relationship between GDP and FDI in case of Turkey. In addition to this, GDP does not Granger Cause with DIN and TL whereas the result also shows that TL Granger causes with GDP because it can reject the hypothesis at 10\% significance level.

In case of short run by using OLS Regression, the table number 2 indicates that in terms of level form of 
variables, there is short-run and positive relationship between GDP and FDI, and also, the p-value of DIN is not significant which is correspondingly higher than $05 \%$.Furthermore, there is negative short-term relationship between DIN with GDP. In contrast, the coefficient of TL is 0.444244 thereby highlighting a positive and insignificant relationship between GDP and TL in case of Turkey. Similarly, by using OLS regression, in case of first difference of variables, the table number 3 indicates that there is insignificant, yet positive, short run relationship between FDI and GDP. Despite this, there is significant and positive short run relationship between DIN and GDP. Conversely, a negative, yet significant, short run relationship between TL and GDP exists.

In spite of these, the result of this study does not accord with previous studies in case of Turkey. For example, Afşar (2007) maintains that there is no mutual causality relationship between FDI and economic growth in Turkey. Nonetheless, there is only causality relationship from economic growths to FDIs. Similarly, Ozturk and Kalyoncu (2007)'s findings assert on the existence of a positive causality relationship between FDI and economic growth in cause of Turkey.

\section{Conclusion}

This paper has attempted to explore a relationship between foreign direct investment, domestic investment and trade liberalization with economic growth (GDP). It has employed annual data over the period of 1980-2012. The empirical result shows that all variable in this paper have a unit root problem in terms of level form by using Augmented Dickey Fuller (ADF) test. But, when the first difference is considered, all the series become stationary at 5 percentage confidence levels. According to the Johansen test's result, all four probabilty values of GDP, FDI,DIN and TL are higher than $05 \%$ percentage significant level, which are $0.2743,0.8816,0.9013$ and 0.5518 respectively in terms of Trace test. Additionally, all four probability values interms of Lmax test and Trace test infer no long run relationship between GDP, FDI, DIN and TL. Also, the cointegration rank of this cointegration is zero as a result of higher level of P-value for all variables, which are higher than $05 \%$ percentage significant level.

Based on the empirical findings and analyses, through using the Vector Autoregression model, this paper has concluded that there is no long run relationship between foreign direct investment and economic growth in Turkey. This paper has inferred that there is no Granger causal relationship between FDI and economic growth by means of using Granger causality test. The current study's findings have further demonstrated the fact that the TL Granger causes with GDP because it can reject the hypothesis at $10 \%$ significance level. However, by using OLS regression in terms of level form of series variables, there is short run relationship between FDI and GDP. It has also illustrated that in the short run, FDI helps in overcoming the lack of capital through implementing domestic investment whereby it substantiates Turkish economic growth.

In contrast, in the first difference form of variables by using OLS regression, the result indicates that there is insignificant and positive short run relationship between GDP and foreign direct investment whereby there is a positive and significant short run relationship between GDP and domestic investment. Moreover, there is a negative and significant short run relationship between GDP and trade liberalization.

\section{References}

Adams, S. (2009). Foreign Direct investment, domestic investment, and economic growth in Sub-Saharan Africa. Journal of Policy Modeling, 31(6), 939-949. http://dx.doi.org/10.1016/j.jpolmod.2009.03.003

Aghion, P. A., Howitt, P. A., \& Peñalosa, C. G. (1998). Endogenous growth theory. MIT press.

Agrawal, G., \& Khan, M. A. (2011). Impact of FDI on GDP: A Comparative Study of China and India. International Journal of Business and Management, 6(10), 71. http://dx.doi.org/10.5539/ijbm.v6n10p71

Akinlo, A. E. (2004). Foreign direct investment and growth in Nigeria: An empirical investigation. Journal of Policy Modeling, 26(5), 627-639. http://dx.doi.org/10.1016/j.jpolmod.2004.04.011

Aktar, I., \& Ozturk, L. (2009). Can unemployment be cured by economic growth and foreign direct investment in Turkey. International Research Journal of Finance and Economics, 27, 203-211.

Arısoy, İ. (2012). The impact of foreign direct investment on total factor productivity and economic growth in Turkey. The Journal of Developing Areas, 46(1), 17-29. http://dx.doi.org/10.1353/jda.2012.0013

Athukorala, P. P. A. (2003, November). The impact of foreign direct investment for economic growth: a case study in Sri Lanka. In 9th International Conference on Sri Lanka Studies, Full Paper (No. 092).

Baharumshah, A. Z., \& Almasaied, S. W. (2009). Foreign direct investment and economic growth in Malaysia: interactions with human capital and financial deepening. Emerging Markets Finance and Trade, 45(1), 90102. http://dx.doi.org/10.2753/REE1540-496X450106 
Balamurali, N., \& Bogahawatte, C. (2004). Foreign Direct Investment and Economic Growth in Sri Lanka. Sri Lankan Journal of Agricultural Economics, 6(1), 37-50.

Bildirici, M., Alp, E. A., \& Kayıkçı, F. (2010). Effects of Foreign Direct Investment on Growth in Turkey. Growth \& Development, 3B, 191-200.

Borensztein, E., De Gregorio, J., \& Lee, J. W. (1998). How does foreign direct investment affect economic $\begin{array}{llll}\text { growth? Journal of International } & \text { Economics, }\end{array}$ http://dx.doi.org/10.1016/S0022-1996(97)00033-0

Brooks, C. (2008). Introductory econometrics for finance. Cambridge University Press. http://dx.doi.org/10.1017/CBO9780511841644

Buckley, P. J., Clegg, J., Wang, C., \& Cross, A. R. (2002). FDI, regional differences and economic growth: panel data evidence from China. Transnational Corporations, 11(1), 1-28.

Cottrell, A., \& Lucchetti, R. (2012). Gretl user's guide. GNU regression, econometric and time series library. GNU Free Documentation License, 1.

Dickey, D. A., \& Fuller, W. A. (1979). Distribution of the estimators for autoregressive time series with a unit root. Journal of the American Statistical Association, 74(366a), 427-431. http://dx.doi.org/10.1080/01621459.1979.10482531

Dinopoulos, E. (2006). Growth in Open Economies, Schumpeterian Models. In K. Reinert \& R. Rajan (Eds.), Princeton Encyclopedia of the World Economy.

Dritsaki, M., Dritsaki, C., \& Adamopoulos, A. (2004). A Causal Relationship between Trade, Foreign Direct Investment and Economic Growth in Greece. American Journal of Applied Sciences, 1(3), 230. http://dx.doi.org/10.3844/ajassp.2004.230.235

Enders, W. (2008). Applied econometric time series. John Wiley \& Sons.

Granger, C. W. (1969). Investigating causal relations by econometric models and cross-spectral methods.Econometrica. Journal of the Econometric Society, 424-438. http://dx.doi.org/10.2307/1912791

Hossain, A., \& Hossain, M. K. (2012). Empirical relationship between foreign direct investment and economic output in South Asian countries: A study on Bangladesh, Pakistan and India. International Business Research $5(1), 9$.

Hsiao, F. S., \& Hsiao, M. C. W. (2006). FDI, exports, and GDP in East and Southeast Asia—Panel data versus time-series causality analyses. Journal of Asian Economics, 17(6), 1082-1106. http://dx.doi.org/10.1016/j.asieco.2006.09.011

Ilgun, E., Koch, K. J., \& Orhan, M. (2010). How Do Foreign Direct Investment and Growth Interact in Turkey? Eurasian Journal of Business and Economics, 3(6), 41-55.

Christian, I. E. (2012). The Impact of Foreign Direct Investment on Nigeria's Economic Growth; 1980-2009: Evidence from the Johansen's Cointegration Approach. International Journal of Business and Social Science, 3(6).

Kiliç, R., \& Ateû, E. (2009). The increasing importance of foreign direct investment and Turkey. Investment Management and Financial Innovations, 6(4), 188-199.

Li, D. (2002). Is the AK model still alive? The long - run relation between growth and investment re-examined. Canadian Journal of Economics/Revue Canadienne D'économique, 35(1), 92-114. http://dx.doi.org/10.1111/1540-5982.00122

MacKinnon, J. G. (2010). Critical values for cointegration tests (No. 1227). Queen's Economics Department Working Paper.

McGrattan, E. R. (1998). A defense of AK growth models. Federal Reserve Bank of Minneapolis Quarterly Review, 22(4), 13-27.

Murray, M. P. (2006). Econometrics: A modern introduction. Pearson Addison Wesley.

Nair-Reichert, U., \& Weinhold, D. (2001). Causality Tests for Cross-Country Panels: a New Look at FDI and Economic Growth in Developing Countries. Oxford Bulletin of Economics and Statistics, 63(2), 153-171. http://dx.doi.org/10.1111/1468-0084.00214

Nellis, J. G., \& Parker, D. (2004). Principles of macroeconomics. Pearson Education. 
Neuhaus, M. (2006). The impact of FDI on economic growth: an analysis for the transition countries of Central and Eastern Europe.

Ozturk, I., \& Kalyoncu, H. (2007). Foreign direct investment and growth: An empiricial investigation based on cross-country comparison.

Qayum, A. (2005). Endogenicity of economic growth models. Technological Forecasting and Social Change, 72(1), 75-84. http://dx.doi.org/10.1016/S0040-1625(02)00318-9

Razin, A., \& Sadka, E. (2012). Foreign direct investment: analysis of aggregate flows. Princeton University Press.

Romer, D. (2012). Advanced macroeconomics (4th ed.). New York: McGraw-Hill.

Saglam, B. B., \& Yalta, A. Y. (2009). Dynamic Linkages among Foreign Direct Investment, Public Investment and Private Investment: Evidence from Turkey. Applied Econometrics and International Development, 11(2).

Sørensen, P. B., \& Whitta-Jacobsen, H. J. (2005). Introducing advanced macroeconomics: growth and business cycles. New York: McGraw-Hill.

Studenmund, A. H. (2006). Using Econometrics: A Practical Guide (5th ed.). Dary Fox.

Sun, H. (2011). Co-integration study of relationship between foreign direct investment and economic growth. International Business Research, 4(4), 226. http://dx.doi.org/10.5539/ibr.v4n4p226

Umoh, O. J., Jacob, A. O., \& Chuku, C. A. (2012). Foreign Direct Investment and Economic Growth in Nigeria: An Analysis of the Endogenous Effects. Current Research Journal of Economic Theory, 4(3), 53-66.

Wooldridge, J. M. (2009). Introductory Econometrics: A Modern Approach (4th ed.). Cengage Learning.

Zhang, K. H. (2001). Does foreign direct investment promote economic growth? Evidence from East Asia and Latin America. Contemporary Economic Policy, 19(2), 175-185. http://dx.doi.org/10.1111/j.1465-7287.2001.tb00059.x

Zhao, C., \& Du, J. (2007). Causality between FDI and economic growth in China. Chinese Economy, 40(6), 6882. http://dx.doi.org/10.2753/CES1097-1475400604

\section{Copyrights}

Copyright for this article is retained by the author(s), with first publication rights granted to the journal.

This is an open-access article distributed under the terms and conditions of the Creative Commons Attribution license (http://creativecommons.org/licenses/by/3.0/). 